\title{
TORREFACTION OF OIL PALM FRONDS (OPF) AS A POTENTIAL FEEDSTOCK FOR ENERGY PRODUCTION PROCESSES
}

\author{
Thuraiya THAIM, Ruwaida ABDUL RASID ${ }^{*}$, Wan Muhamad Syafiq WAN ISMAIL \\ Faculty of Chemical \& Natural Resources Engineering, Universiti Malaysia Pahang, \\ 26300 Gambang, Pahang, Malaysia
}

Received 01 August 2017; accepted 05 October 2018

\begin{abstract}
Oil palm fronds (OPF) and trunks contribute the highest biomass availability compared with other oil palm wastes. At the moment, they are usually left on the ground around the plantation area to decompose naturally and fertilize the soil. Previous researchers have focused on torrefaction of wood residues and other agricultural biomass with less attention has been paid to the utilization of Malaysia's biomass such as OPF. Therefore, in this study, torrefaction of OPF was conducted in a tubular reactor at temperatures between 200 and $300{ }^{\circ} \mathrm{C}$ and residence time of $30 \mathrm{~min}$. The results reveal an improved heating value as the temperature was increased, from 16.81 to $20.32 \mathrm{MJ} / \mathrm{kg}$ after the torrefaction process. The van Krevelen diagram also proved that torrefaction OPF could be classified as an intermediate, between raw OPF and coal. This proves the potential of OPF as one of the alternative feedstocks for energy production process through torrefaction.
\end{abstract}

Keywords: torrefaction, biomass, Oil palm frond (OPF), waste management technology, renewable energy.

\section{Introduction}

Renewable biomass can be used as a fuel to reduce the dependency on fossil fuel for the production of heat, steam, and electricity for residential, industrial, and agricultural use. Replacing fossil fuels with biomass is more beneficial as it may reduce pollution and global warming. The palm oil industry is growing so fast and Malaysia is the second largest palm oil producer with estimated wastes of around 80 million dry tons (Umar, Jennings, \& Umee, 2014). Furthermore, oil palm trees are being replanted to ensure sustainable oil productions, replacing low yields of ageing trees (Kamalrudin \& Abdullah, 2014). Specifically, in Malaysia, Malaysia Palm Oil Board (MPOB) has even introduces Replanting Incentive Scheme to encourage oil palm tree replantation (Wahid \& Simeh, 2010), warranting the continuous production of oil palm, and its biomass wastes.

The palm oil industry generates an abundance of biomass wastes in which only $10 \%$ of the tree is recovered as oil, leaving $90 \%$ as biomass waste in the forms of empty fruit brunch (EFB), palm kernel shell (PKS), oil palm frond (OPF), trunks, fiber, and palm oil mill effluent (POME) (Sukiran, Abnisa, Daud, Bakar, \& Loh, 2017). As of July 2018, Malaysia has produced 10 million tonnes of crude palm oil (CPO) whereby 45 million tonnes of fresh fruit bunch (FFB) was processed (MPOB, 2018). However, $\mathrm{OPF}$ is produced from the pruning of the palm trees in the plantation, and is produced continuously, generating up to 52 million tonnes of OPF per year (Sukiran et al., 2017). These wastes can be further utilized and developed as a one of the renewable energy sources which simultaneously minimizes the environmental problems and pollution. The current application of OPF includes roughage source in animal feed (Zahari, Abu Hassan, Wong, \& Liang, 2003), raw material for biocomposites (Shinoj, Visvanathan, Panigrahi, \& Kochubabu, 2011), converted to medium density fiber board (MDF), plywood or lumber for furniture manufacturing (Sukiran et al., 2017) while its juice has also been demonstrated as a source of carbohydrate, hence a sustainable carbon source (Tan, Jahim, Harun, Wu, \& Mumtaz, 2016).

Oil palm biomass is found to have high potential energy value and its continuous availability can be utilized for renewable energy production for Malaysia. Due to its physical characteristics, oil palm biomass can be a useful feedstock to generate energy. One of the methods to convert biomass into useful feedstock is through torrefaction process. Torrefaction is a biomass thermal pretreatment technique at temperatures ranging from 200 to $300{ }^{\circ} \mathrm{C}$

*Corresponding author. E-mail: ruwaida@ump.edu.my 
(Rousset, Macedo, Commandré, \& Moreira, 2012). Torrefaction is important to improve the biomass quality and reduce some of its problem such as low heating value and energy density, high moisture content (MC), low combustion efficiency, and high grinding energy requirements. Torrefaction increases the energy density of biomass by reducing its oxygen content leading to a solid biomass product with heating values nearing that of coal (Chen, Chua, \& Lee, 2017). Torrefaction produces three products which are solid product, acidic aqueous products, and non-condensable gaseous products. The main product of the torrefaction process is the solid product which is also called as torrefied biomass. Torrefaction process can be divided into light torrefaction $\left(200-240^{\circ} \mathrm{C}\right)$ and severe torrefaction $\left(260-300^{\circ} \mathrm{C}\right)$ (Sabil, Aziz, Lal, \& Uemura, 2013). Torrefied biomass is able to retain most of its chemical energy and can be ground easily compared with those of its original form. In addition, torrefied biomass has increased uniformity and improved quality in terms of its physical and chemical properties (Barta-Rajnai et al., 2016). The torrefied solids may be applied for energy production processes such as combustion, gasification, or production of bio-oil through pyrolysis (Louwes et al., 2017).

Torrefaction process is highly affected by the temperature in which the biomass is subjected to. This is true for various types of biomass such as mesocarp fiber and palm kernel in densified form (Mohd Faizal et al., 2018) and original form (Sabil et al., 2013), EFB (Abdul Rasid \& Yusoff, 2017), and bamboo (M. F. Li, X. Li, Bian, \& Chen, 2015). These studies mainly found that the increase of temperature decreased the percentage of mass and energy yields (Li et al., 2015; Abdul Rasid \& Yusoff, 2017). Mass and energy yield are the significant indicators to determine the optimum parameter while considering also the higher heating value $(\mathrm{HHV})$. Besides, when the calorific value increases, the moisture content and volatile matter decrease, with increased temperature and residence time (Sabil et al., 2013; Mohd Faizal et al., 2018). This is mainly due to the increase in devolatization rate and decomposition of hemicellulose and cellulose when temperature increases.

However, the mass yield could be reduced too much at severe temperature, and longer residence time due to carbonization, dehydrogenation, and deoxygenation (Zhang et al., 2018). It was also observed that the color of the biomass changed from light brown to dark brown and dark black due to the structural modification of lignin and the formation of more chromophoric groups (Li et al., 2015) which may be related to light carbonization (Abdul Rasid \& Yusoff, 2017). Severe temperature plays a more significant role in torrefied biomass properties, due to the decomposition of its lignocellulosic components, which are cellulose, hemicellulose as well as lignin, which becomes more significant, causing a significant weight loss of the biomass samples.

Previous researchers have focused on torrefaction forest residues (Macedo, Commandré, Rousset, Valette, \& Pétrissans, 2018; Doddapaneni et al., 2017). Malaysia has the potential in the utilization of its own agricultural biomass as they have been receiving little or no attention, especially oil palm wastes such as OPF. OPF is a byproduct of the cultivation of oil palm trees. OPF is either utilized or discarded at plantations and has not been optimally used. OPF contributes $14.71 \%$ (97 million tons per year) from the total oil palm wastes on a wet basis (Guangul, Sulaiman, \& Ramli, 2012). They are usually left on the ground to decompose and fertilize the soil. There are limited studies on OPF torrefaction available in the literature, although studies on gasification have been done (Guangul et al., 2012). Hence, it is the aim of the present study to investigate the effect of torrefaction temperature on the characteristics of OPF as a potential renewable energy source through the torrefaction process.

\section{Research methodology}

\subsection{Materials and analysis}

OPF was obtained from Felda Lepar Hilir, Gambang, Kuantan, Pahang, Malaysia in 2016, where the average oil palm trees is approximately 10 years. Coal sample was obtained from TNB Research for comparison purposes. OPF sample was oven-dried at $105^{\circ} \mathrm{C}$ for $24 \mathrm{~h}$ to provide a basis of the tested materials and to determine the ovendry mass before torrefaction. After drying, the samples were ground and sieved into consistent size distribution of 250-500 $\mu \mathrm{m}$. Then, the dried samples were transferred into labelled air-tight containers that contained silica gel to control MC and the samples were stored until further use. The ultimate analysis provides the composition of carbon $(\mathrm{C})$, hydrogen $(\mathrm{H})$, nitrogen $(\mathrm{N})$, sulfur $(\mathrm{S})$ using Perkin Elmer 2400 Series, in Central Lab, UMP. The oxygen (O) element was calculated by difference. The raw OPF and coal properties are shown in Table 1.

Table 1. Properties of raw OPF and coal

\begin{tabular}{|l|c|c|c|c|c|c|}
\hline & \multicolumn{5}{|c|}{ Ultimate analysis (wt.\%) } & \multirow{2}{*}{$\begin{array}{c}\text { HHV } \\
(\mathrm{M} / \mathrm{kg})\end{array}$} \\
\cline { 2 - 6 } & $\mathrm{C}$ & $\mathrm{H}$ & $\mathrm{N}$ & $\mathrm{S}$ & $\mathrm{O}$ & \\
\hline $\begin{array}{l}\text { Raw } \\
\text { OPF }\end{array}$ & 42.26 & 7.03 & 2.81 & 0.22 & 47.68 & 16.81 \\
\hline Coal & 63.35 & 5.81 & 1.21 & 0.25 & 29.39 & 26.03 \\
\hline
\end{tabular}

\subsection{Torrefaction experiment}

The torrefaction of biomass was carried out using a vertical tubular stainless steel reactor as shown in Figure 1. A prescribed amount of biomass wastes $(8.0 \mathrm{~g})$ was weighed and placed in the reactor. The nitrogen $\left(\mathrm{N}_{2}\right)$ gas was supplied from a cylinder tank at $30 \mathrm{~mL} / \mathrm{min}$. The sample was heated up to the desired temperatures at a heating rate of $10^{\circ} \mathrm{C} / \mathrm{min}$ and once the desired temperature was achieved the reaction was allowed to take place for $30 \mathrm{~min}$. The biomass was cooled down to room temperature before the torrefied biomass was retrieved and weighed. The torrefaction experiment was replicated at least three times to ensure consistency. 


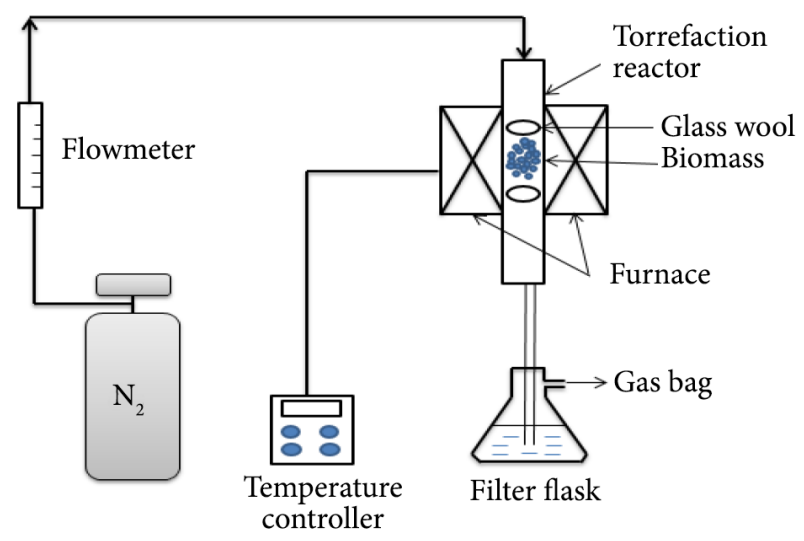

Figure 1. Schematic diagram of the experimental setup

\subsection{Measurements}

The mass yield, energy yield, and HHV were calculated according to Equations (1), (2), and (3) (Uemura, Omar, Tsutsui, \& Yusup, 2011). Mass yield can be defined as the percentage of biomass solid retained after torrefaction process ( $\mathrm{g}$ ) divided by the initial mass before torrefaction (g) as shown in Equation (1):

$$
y_{m}=\frac{m_{T}}{m_{O}} \times 100 \%,
$$

where $y_{m}$ is the mass yield (\%), $m_{O}$ and $m_{T}$ are the initial and final masses of solid (g), respectively. Energy yield indicates the total energy preserved in the torrefied biomass as shown in Equation (2):

$$
y_{E}=y_{m} \times \frac{H H V_{T}}{H H V_{O}},
$$

where is the energy yield (\%), and $H H V_{T}$ and $H H V_{O}$ are the higher heating values of torrefied and initial biomass, respectively. The HHV value is defined as the amount of heat released by a specified quantity (initially at $25^{\circ} \mathrm{C}$ ) once it is combusted and the products have returned to an initial temperature as shown in Equation (3):

$$
H H V=0.4373 Z_{c}-1.6701
$$

where $Z_{c}$ is the weight percentage (\%) of elemental carbon. In addition, energy density is the amount of energy stored in a given system or region of space per unit volume as shown in Equation (4):

$$
E_{D}=\frac{y_{E}}{y_{m}} \times 100 \%,
$$

where $E_{D}$ is the energy density.

\section{Results and discussions}

\subsection{Mass and energy yield}

Mass yield can be defined as the percentage of biomass solid retained after torrefaction process (Equation (1)).
The mass yield of the torrefied OPF at different temperature is shown in Figure 2. Torrefaction process can be divided into light torrefaction (performed at 200, 220, and $240{ }^{\circ} \mathrm{C}$ ) and severe torrefaction (performed at 260 , 280 , and $300^{\circ} \mathrm{C}$ ) (Sabil et al., 2013). The percentage of mass yield decreased with the increase in the operating temperature. This trend is consistent with the findings in the literature (Samad, Jamin, \& Saleh, 2017; Mohd Faizal et al., 2018; Conag, Villahermosa, Cabatingan, \& Go, 2018). The highest mass yield was $91.65 \%$ for the torrefaction at $200{ }^{\circ} \mathrm{C}$, the mildest temperature. Meanwhile, the lowest mass yield was $68.96 \%$ obtained from the torrefaction process at $300{ }^{\circ} \mathrm{C}$. Light torrefaction did not show any significant difference of mass yield for all temperatures.

From the viewpoint of mass yield, light torrefaction showed insignificant effect because of a little decrement from its original weight. The mass yield of light torrefaction was around $89-92 \%$ with an overall mass loss of $8-11 \%$. The little decrement in light torrefaction might be due to the drying process occurred at below $220^{\circ} \mathrm{C}$. The decreasing of mass yield could be related to the proximate analysis where the MC and volatile matters decrease when the temperature increases (Wahid, Saleh, \& Samad, 2017).

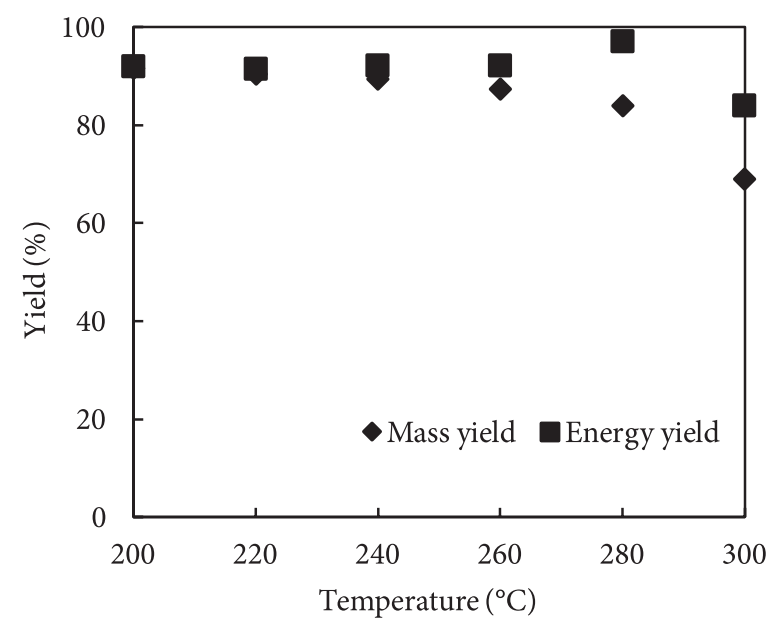

Figure 2. Mass and energy yield

Energy yield is important to measure torrefied biomass in terms of its energy density (Equation (2)). Energy density is defined as the amount of chemical energy stored in fuel per unit volume and if the energy density is more than unity then the desired energy gain can be achieved (Cellatoglu \& Ilkan, 2015). Energy yield percentages at different temperatures for OPF are shown to have a decreasing trend as shown in Figure 2. It could be easily noticed that the torrefaction at $280{ }^{\circ} \mathrm{C}$ gave a higher energy yield compared to those performed at other temperatures. The decrement of energy yield may be caused by further decomposition of hemicellulose and cellulose in the biomass (Sabil et al., 2013). The observation result is consistent with previous works (Rodriguez, Martin-Lara, Blazquez, \& Perez, 2017; Samad et al., 2017). 
The energy density profile of OPF is shown in Figure 3. The energy density increased significantly at the temperature exceeding $240{ }^{\circ} \mathrm{C}$ and remained rather constant at $300{ }^{\circ} \mathrm{C}$. It could be seen that for all temperatures, the energy density is greater than one of energy density, which suggests that the energy gain is achieved for torrefaction process based on definition of energy density. For OPF, the highest relative energy gain was at $300^{\circ} \mathrm{C}$. The energy density increases against temperature due to the increase of calorific value which is important to decrease the volume of biomass as a feedstock especially in biomass cofiring plant, as the torrefied biomass properties is similar to coal (Chen et al., 2017).

\subsection{Ultimate analysis}

The elemental analysis in terms of $\mathrm{C}, \mathrm{H}, \mathrm{N}, \mathrm{S}$, and $\mathrm{O}$ of the raw and torrefied biomass OPF is shown in Figure 4. Torrefaction increased the $\mathrm{C}$ content in the biomass along with the increasing temperature. The opposite was observed for $\mathrm{H}$ and $\mathrm{O}$ contents where both seemed to decrease with the increasing temperature. Previous researchers had also reported the same trend for $\mathrm{C}, \mathrm{H}$, and O contents (Iroba, Baik, \& Tabil, 2017; Recari et al., 2017). The increment of the $\mathrm{C}$ content for OPF was around $19 \%$ at $300{ }^{\circ} \mathrm{C}$ compared with that of the raw OPF. These results indicate that torrefaction has a positive impact on the $\mathrm{C}$ content. The decrement of $\mathrm{H}$ and $\mathrm{O}$ content is mainly due to the dehydration of the biomass (Prins, Ptasinski, \& Janssen, 2006). On the other hand, the increase in sulfur content is mainly due to the decreased for both the oxygen and hydrogen content at higher temperature, that essentially balances the weight percentages of the elements.

The changes in composition resulted in a decrease of $\mathrm{O} / \mathrm{C}$ ratio. In general, raw OPF contains a low carbon content (43\%) and high oxygen content (48\%). However, coal contains a high carbon content (63\%) and low oxygen content (30\%). Figure 5 shows the O/C ratios of the torrefied biomass at different temperatures. The torrefaction process had positive influence to reduce the $\mathrm{O} / \mathrm{C}$ ratio especially at more severe torrefaction temperature. The $\mathrm{O} / \mathrm{C}$ ratio decreased by approximately $70 \%$. The decrement of $\mathrm{O} / \mathrm{C}$ ratio implies that there will be less smoke and vapor formation as well as reduction in energy loss during subsequent combustion and gasification processes (Tumulu, Sokhansanj, Wright, \& Boardman, 2011).

To compare the OPF results with coal, a van Krevelen diagram was plotted as shown in Figure 6. The van Krevelen diagram is the graph of $\mathrm{O} / \mathrm{C}$ ratio versus $\mathrm{H} / \mathrm{C}$ ratio. As temperature increased, the $\mathrm{O} / \mathrm{C}$ and $\mathrm{H} / \mathrm{C}$ ratio are closer to those of coal. Before torrefaction, raw OPF had an $\mathrm{O} / \mathrm{C}$ ratio of 1.13 and an $\mathrm{H} / \mathrm{C}$ ratio of 0.17 . At $300{ }^{\circ} \mathrm{C}$, these $\mathrm{O} / \mathrm{C}$ and $\mathrm{H} / \mathrm{C}$ ratios were reduced to 0.67 and 0.11 , respectively. Torrefied OPF could be classified as an intermediate product between raw OPF and coal. This is due to drying and devolatilization processes in torrefaction that remove surface water and carbon dioxide (Prins et al.,
2006). The van Krevelen diagram proved that the torrefied OPF can potentially be used as a feedstock for combustion and gasification since the physical properties are almost as similar as coal, as shown by lower and improved $\mathrm{O} / \mathrm{C}$ and $\mathrm{H} / \mathrm{C}$ ratio. This is especially evident at $300{ }^{\circ} \mathrm{C}$.

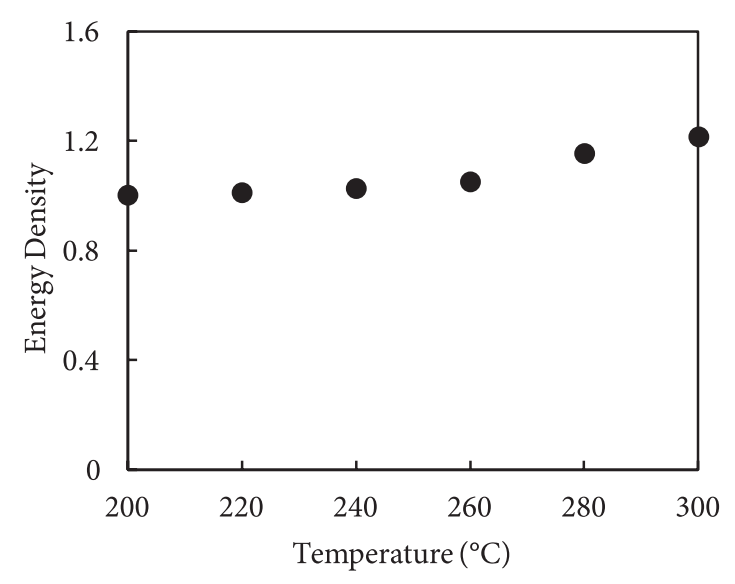

Figure 3. Energy density

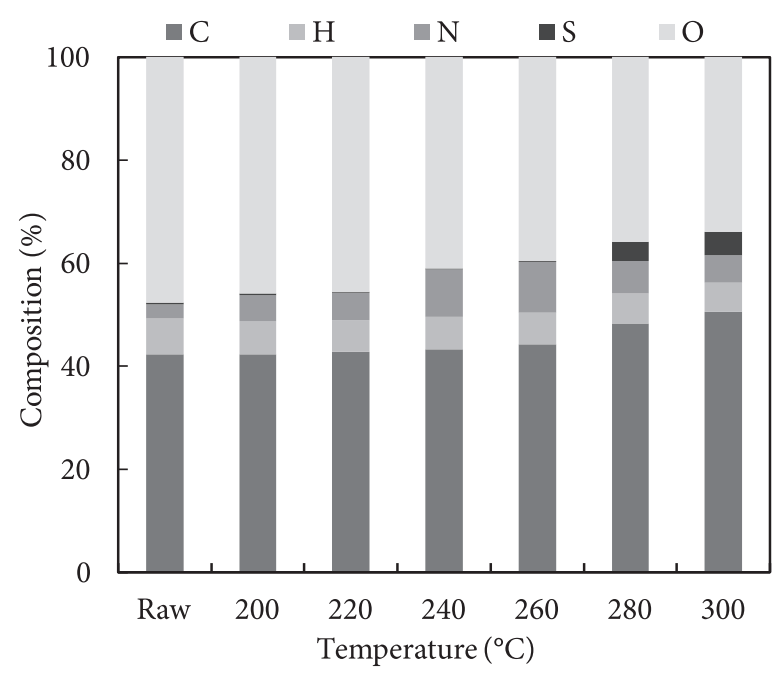

Figure 4. Ultimate analysis for OPF

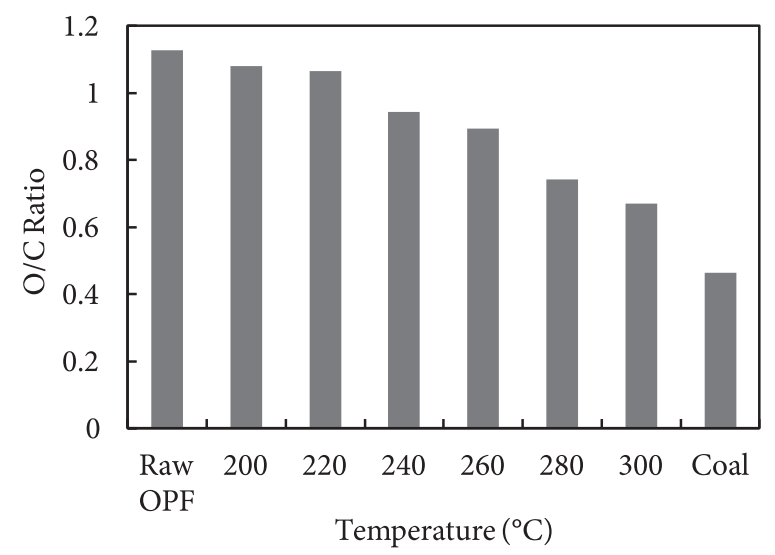

Figure 5. Effect of temperature on $\mathrm{O} / \mathrm{C}$ ratio 


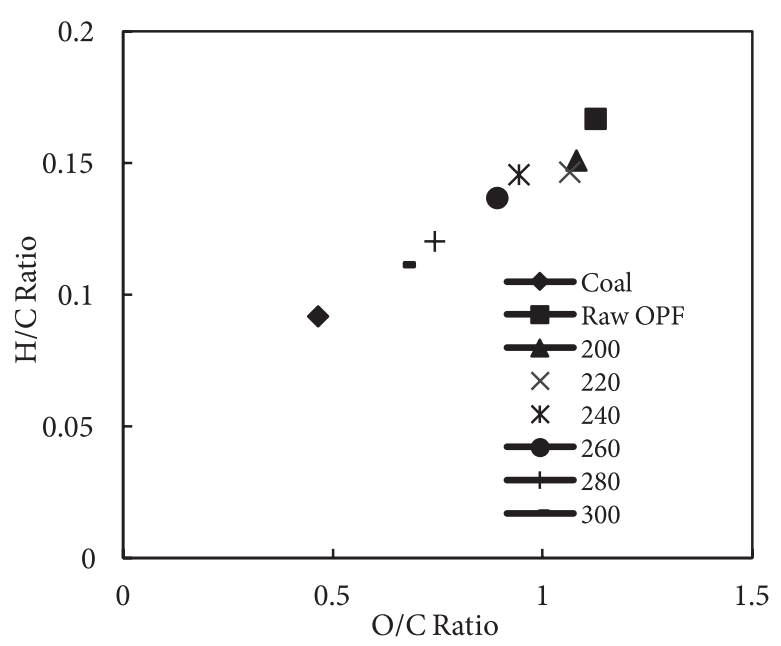

Figure 6. van Krevelen diagram of OPF

\subsection{Proximate analysis}

Table 2 presents the values of MC, volatiles matter (VM), fixed carbon (FC), and ash content (AC) for all samples before and after torrefaction. When the temperature was increased, MC and VM decreased, while the opposite was observed for FC and AC. The MC of torrefied OPF decreased significantly to $4.40 \%$ compared with that of the raw OPF (6.86\%), which can be related to the decrease of mass yield. These results are in agreement with a previous study (Recari et al., 2017).

The percentages of moisture loss for each biomass were different for each biomass; bagasse (81-89\%) and water hyacinth (83-89\%) were higher than rice husks (70-84\%), sawdust (71-82\%), and peanut husks (71-79\%). For gasification application, high $\mathrm{MC}$ is not favorable as it can reduce the feedstock heating value and in turn requires more energy for an efficient gasification process. However, $\mathrm{MC}$ around $20-35 \%$ can be considered for gasification depending on the type of gasifiers used (Bridgwater, Toft, \& Brammer, 2002).

Table 2. Proximate analysis

\begin{tabular}{|c|c|c|c|c|}
\hline $\mathrm{T}\left({ }^{\circ} \mathrm{C}\right)$ & $\mathrm{MC}$ & $\mathrm{VM}$ & $\mathrm{FC}$ & $\mathrm{AC}$ \\
\hline Raw OPF & 6.86 & 79.22 & 0.24 & 13.68 \\
\hline 200 & 6.54 & 78.46 & 4.36 & 10.64 \\
\hline 220 & 5.99 & 72.56 & 9.31 & 12.14 \\
\hline 240 & 5.37 & 71.74 & 9.93 & 12.95 \\
\hline 260 & 5.40 & 67.30 & 11.39 & 15.91 \\
\hline 280 & 5.35 & 65.48 & 10.54 & 18.93 \\
\hline 300 & 4.71 & 63.41 & 9.79 & 22.09 \\
\hline Coal & 8.54 & 39.69 & 38.62 & 13.15 \\
\hline
\end{tabular}

The VM content decreased from $79.22 \%$ to $63.41 \%$ across the temperature range, while the FC content increased from $3.23 \%$ to $12.01 \%$. These trends are consistent with the compositional analysis results published by other researchers (Rodriguez et al., 2017; Conag et al., 2018).
High VM content is not favorable during gasification or combustion as it can cause excessive volatilization that can contribute to the formation of tar, soot, and smoke that affect the efficiency of gasification (Van der Stelt, Gerhauser, Kiel, \& Ptasinski, 2011). The decrease in the MC and VM contents solved the storage problems of raw samples, where the reactivity of the torrefied biomass is reduced in storage (Tumulu et al., 2011). An increase in FC is suitable for further use in energy production processes as high FC can also increase the char formation during gasification process (Van der Stelt et al., 2011), which may increase the $\mathrm{CO}$ production during gasification. The AC increased steadily from $8.68 \%$ to $21.15 \%$. Light torrefaction resulted in lower $\mathrm{AC}$ values compared with that of severe torrefaction, although sometimes high AC is needed for biomass gasification to induce the catalytic effect which may cause the cracking of high molecular weight compounds formed during gasification and change gasification dynamics (Fahmi, Bridgwater, Donnison, \& Yates, 2008).

Fuel ratio is the ratio of FC content to VM content and can be used to evaluate the combustibility of coal and biochar (Huang, Suang, Chiueh, \& Lo, 2017). Figure 7 illustrates the fuel ratio of raw and torrefied OPF where the values are all lower than 0.2 . The fuel ratio for the torrefied $\mathrm{OPF}$ at $260{ }^{\circ} \mathrm{C}$ was the highest at 0.169 while at $300{ }^{\circ} \mathrm{C}$, it was 0.154 . The fuel ratio of coal on the other hand was 0.973 . The issue here is that OPF could be an alternative renewable energy source but in terms of quality, OPF still far away than coal on the basis of fuel ratio. A way to improve the fuel ratio may be through combining the torrefied OPF with coal for co-combustion and co-gasification applications. The oil palm wastes can still be utilized due to its availability and at the same time can minimize environmental problems caused by coal. Further investigation in the future needs to be done to further clarify this.

\subsection{Higher Heating Value (HHV)}

Direct use of raw biomass as a fuel is inefficient due to its low calorific value, as it reduces the efficiency of the process. Therefore, torrefaction process increases the calorific

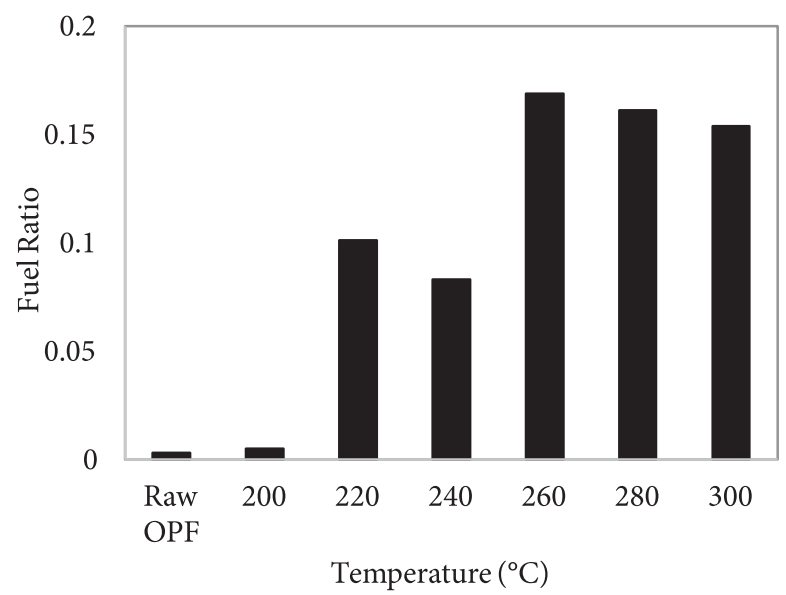

Figure 7. Fuel ratio of OPF 


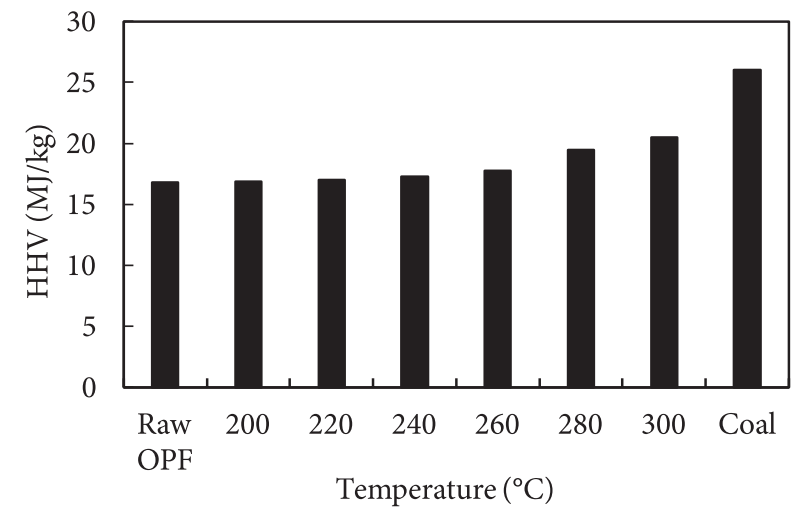

Figure 8. Higher heating value (HHV) for raw and torrefied OPF compared to coal value as a function of temperature. From Figure 8, the HHV increased with the increasing torrefaction temperature. This result seems to be in a good agreement with the literatures (Irawan, Latifah Upe, \& Meity Dwi, 2017; Cai, Fivga, Kaario, \& Liu, 2017). At a temperature below $260{ }^{\circ} \mathrm{C}$, the effect of temperature on the HHV is not as significant compared with that at higher temperature. This could be related to the increase on FC in the torrefied OPF (Mohd Faizal et al., 2018). Overall, the increase of the HHV of the torrefied OPF is about $0.34-21.70 \%$. It is also important to highlight that the HHV of torrefied $\mathrm{OPF}$ is almost similar to coal especially at $300{ }^{\circ} \mathrm{C}$, which indicates its suitability for industrial applications, such as in combustion and gasification.

Table 3. Surface structure of torrefied OPF

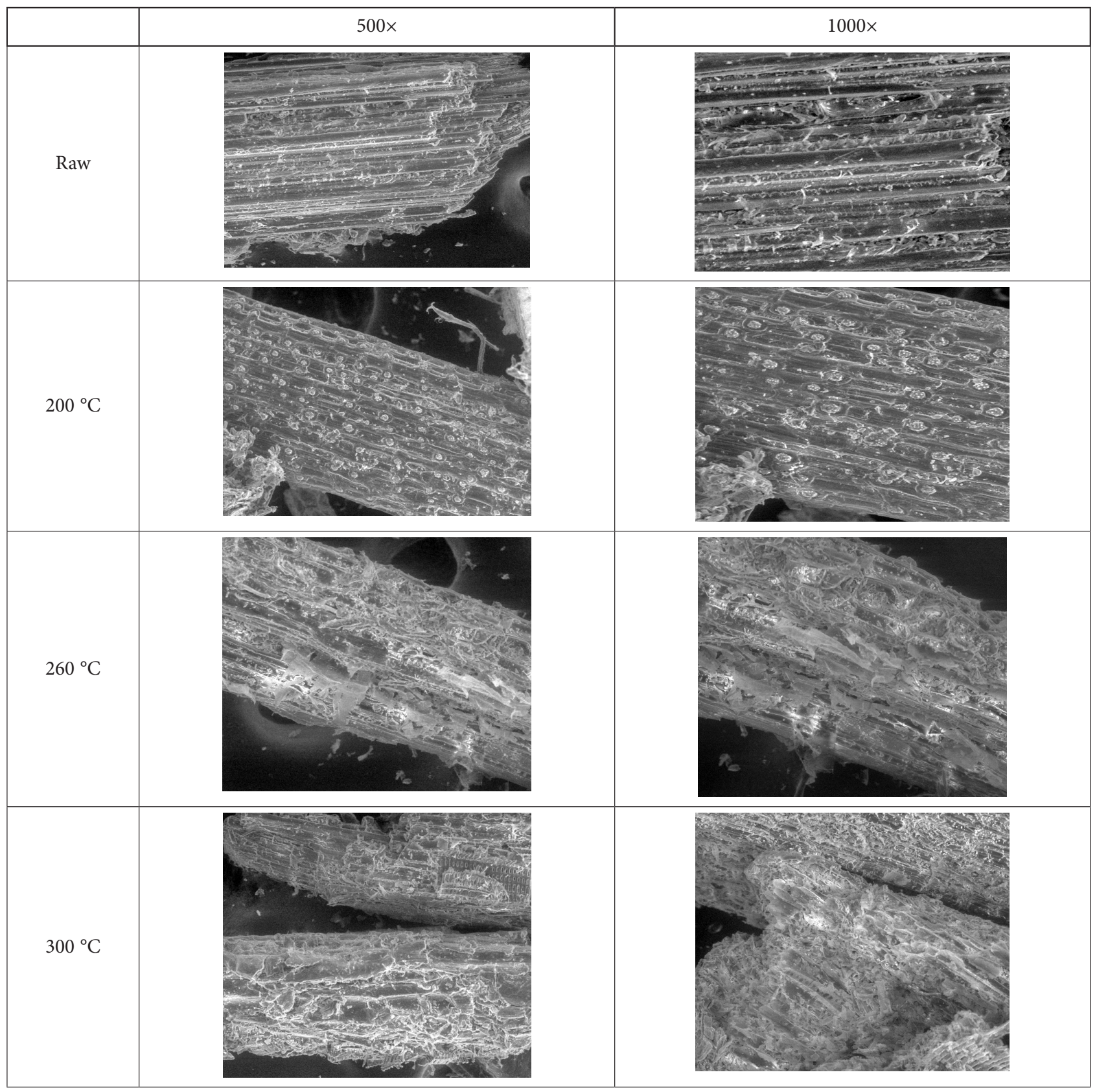




\subsection{Surface morphology}

Table 3 shows the changes on the surface structure of raw and torrefied OPFs under 500 $\times$ and $1000 \times$ magnifications. The presence of horizontal lines was due to the fibrous structure of the OPF. At $200{ }^{\circ} \mathrm{C}$, pores were clearly observed at both $500 \times$ and $1000 \times$ magnifications. These pores were present because they are fibrous materials. These observations were in a good agreement with the literature (Sabil et al., 2013). The changes of surface structure were more obvious at $260{ }^{\circ} \mathrm{C}$. The pores disappeared at this temperature as observed at $1000 \times$ magnification because the fiber structure disassembled that might be due to decomposition. At $300{ }^{\circ} \mathrm{C}$, the OPF structure degraded and in turn changed their internal structure. This is due to the decomposition temperature of hemicellulose, as OPF started to decompose at lower temperature of $150{ }^{\circ} \mathrm{C}$. Meanwhile, at $300{ }^{\circ} \mathrm{C}$ severe decomposition occurred on the surface structure of OPF. On the basis of this observation, the decomposition temperature of hemicellulose can be said to affect the internal structure of OPF.

\section{Conclusions}

In this work, the characteristics of OPF as a potential energy source have been studied.

- It was found that the increase in torrefaction temperature leads to a reduction in mass and energy yields. The HHV of the torrefied OPF increased with increasing temperature. The most optimum temperature to achieve this is $300^{\circ} \mathrm{C}$.

- The results were also compared to raw OPF and coal which revealed that the characteristics of the torrefied OPF at more severe torrefaction temperature are almost similar to coal characteristics.

- The van Krevelen diagram proved that the torrefied OPF had the characteristics to allow it to be classified as an intermediate product between raw OPF and coal.

- This indicates that the torrefied OPF can be potentially used as a renewable and alternative feedstock for energy production processes such as the gasification and combustion application since the physical properties are almost similar with coal physical properties.

\section{Acknowledgments}

The authors are grateful for the financial support from Universiti Malaysia Pahang (RDU150366 Oxidative Torrefaction for Biomass Co-gasification, and PGRS170305 Biomass Torrefaction for Gasification).

\section{References}

Abdul Rasid, R., \& Yusoff, M. H. M. (2017). The potential of $\mathrm{CO}_{2}$ torrefaction as biomass Pre-treatment method. Indian Journal of Science and Technology, 10(7), 1-5. https://doi.org/10.17485/ijst/2017/v10i7/111462
Barta-Rajnai, E., Jakab, E., Sebestyén, Z., May, Z., Barta, Z., Wang, L., Skreiberg, Ø., Grønli, M., \& Czegeny, Z. (2016). Comprehensive compositional study of torrefied wood and herbaceous materials by chemical analysis and thermoanalytical methods. Energy Fuels, 30(10), 8019-8030. https://doi.org/10.1021/acs.energyfuels.6b01030

Bridgwater, A. V., Toft, A. J., \& Brammer, J. G. (2002). A technoeconomic comparison of power production by biomass fast pyrolysis with gasification and combustion. Renewable and Sustainable Energy Reviews, 6(3), 181-246. https://doi.org/10.1016/S1364-0321(01)00010-7

Cai, W., Fivga, A., Kaario, O., \& Liu, R. (2017). Effects of torrefaction on the physicochemical characteristics of sawdust and rice husk and their pyrolysis behaviour by thermogravimetric analysis and pyrolysis-gas chromatography/mass spectrometry. Energy Fuels, 31(2), 1544-1554.

https://doi.org/10.1021/acs.energyfuels.6b01846

Cellatoglu, N., \& Ilkan, M. (2015). Torrefaction of solid olive mill residues. Bioresources, 10, 5876-5889. https://doi. org/10.15376/biores.10.3.5876-5889

Chen, W.-H., Chua, Y.-S., \& Lee, W.-J. (2017). Influence of biosolution pretreatment on the structure, reactivity and torrefaction of bamboo. Energy Conversion and Management, 141, 244-253. https://doi.org/10.1016/j.enconman.2016.08.043

Conag, A. T., Villahermosa, J. E. R., Cabatingan, L. K., \& Go, A. W. (2018). Energy densification of sugarcane leaves through torrefaction under minimized oxidative torrefaction. Energy for Sustainable Development, 42, 160-169.

Doddapaneni, T. R., Praveenkumar, R., Tolvanen, H., Palmroth, M. R., Konttinen, J., \& Rintala, J. (2017). Anaerobic batch conversion of pine wood torrefaction condensate. Bioresource Technology, 225, 299-307. https://doi.org/10.1016/j.biortech.2016.11.073

Fahmi, R., Bridgwater, A. V., Donnison, I., \& Yates, N. (2008). The effect of lignin and inorganic species in biomass on pyrolysis oil yields, quality and stability. Fuel, 87(7), 1230-1240. https://doi.org/10.1016/j.fuel.2007.07.026

Guangul, F. M., Sulaiman, S. A., \& Ramli, A. (2012). Gasifier selection, design and gasification of oil palm fronds with preheated and unheated gasifying air. Bioresource Technology, 126, 224-232. https://doi.org/10.1016/j.biortech.2012.09.018

Huang, Y. F., Suang, H. T., Chiueh, P. T., \& Lo, S. L. (2017). Microwave torrefaction of sewage sludge and leucaena. Journal of the Taiwan Institute of Chemical Engineers, 70, 236-243. https://doi.org/10.1016/j.jtice.2016.10.056

Irawan, A., Latifah Upe, S., \& Meity Dwi, I. P. (2017). Effect of torrefaction process on the coconut shell energy content for solid fuel. AIP Conference Proceedings, 1826, 020010. https://doi.org/10.1063/1.4979226

Iroba, K. L., Baik, O. D., \& Tabil, L. G. (2017). Torrefaction of biomass from municipal solid waste fractions I: Temperature profiles, moisture content, energy consumption, mass yield and thermochemical properties. Biomass and Bioenergy, 105, 320-330. https://doi.org/10.1016/j.biombioe.2017.07.009

Kamalrudin, M. S., \& Abdullah, R. (2014). Malaysian palm oil moving ahead to sustainable production growth. Oil Palm Industry Economic Journal, 14, 24-33.

Li, M. F., Li, X., Bian, J., \& Chen, C. Z. (2015). Effect of temperature and holding time on bamboo torrefaction. Biomass and Bioenergy, 83, 366-372. https://doi.org/10.1016/j.biombioe.2015.10.016

Louwes, A., Basile, L., Yukananto, R., Bhagwandas, J., Bramer, E. A., \& Brem, G. (2017). Torrefied biomass as feed for fast 
pyrolysis: An experimental study and chain analysis. Biomass and Bioenergy, 105, 116-126.

https://doi.org/10.1016/j.biombioe.2017.06.009

Macedo, L. A., Commandré, J.-M., Rousset, P., Valette, J., \& Pétrissans, M. (2018). Influence of potassium carbonate addition on the condensable species released during wood torrefaction. Fuel Processing Technology, 168, 248-257. https://doi.org/10.1016/j.fuproc.2017.10.012

Mohd Faizal, H., Shamsuddin, H. S., Heiree, M. H. M., Hanaffi, M. F. M. A., Abdul Rahman, M. R., Mizanur Rahman, Md., \& Latiff, Z. A. (2018). Torrefaction of densified mesocarp fiber and palm kernel shell. Renewable Energy, 122, 419-428. https://doi.org/10.1016/j.renene.2018.01.118

MPOB. (2018). Retrieved August 17, 2018 from https://bepi. mpob.gov.my/index.php/en/

Prins, M. J., Ptasinski, K. J., \& Janssen, F. J. J. G. (2006). More efficient biomass gasification via torrefaction. Energy, 31, 34583470. https://doi.org/10.1016/j.energy.2006.03.008

Rousset, P., Macedo, L., Commandré, J. M., \& Moreira, A. (2012). Biomass torrefaction under different oxygen concentrations and its effect on the composition of the solid by-product. Journal of Analytical and Applied Pyrolysis, 96, 86-91. https://doi.org/10.1016/j.jaap.2012.03.009

Recari, J., Berrueco, C., Puy, N., Alier, S., Bartroli, J., \& Farriol, X. (2017). Torrefaction of a solid recoverd fuel (SRF) to improve the fuel properties for gasification processes. Applied Energy, 203, 177-188. https://doi.org/10.1016/j.apenergy.2017.06.014

Rodriguez, I. I., Martin-Lara, M. A., Blazquez, G., \& Perez, A. (2017). Effects of torrefaction conditions on greenhouse crop residue: Optimization of conditions to upgrade solid characteristics. Bioresource Technology, 244, 741-749. https://doi.org/10.1016/j.biortech.2017.08.031

Sabil, K. M., Aziz, M. A., Lal, B., \& Uemura, Y. (2013). Effects of torrefaction on the physiochemical properties of oil palm empty fruit bunches, mesocarp fiber and kernel shell. Biomass and Bioenergy, 56, 351-360. https://doi.org/10.1016/j.biombioe.2013.05.015

Samad, N. A. F. A., Jamin, N. A., \& Saleh, S. (2017). Torrefaction of municipal solid waste in Malaysia. Energy Procedia, 138, 313-318. https://doi.org/10.1016/j.egypro.2017.10.106

Shinoj, S., Visvanathan, R., Panigrahi, S., \& Kochubabu, M. (2011). Oil palm fiber (OPF) and its composites: A review.
Industrial Crops and Products, 33(1), 7-22.

https://doi.org/10.1016/j.indcrop.2010.09.009

Sukiran, M. A., Abnisa, F., Daud, W. M., Bakar, N. A., \& Loh, S. K. (2017). A review of torrefaction of oil palm solid wastes for biofuel production. Energy Conversion and Management, 149, 101-120. https://doi.org/10.1016/j.enconman.2017.07.011

Tan, J. P., Jahim, J., Harun, S., Wu, T. Y., \& Mumtaz, T. (2016). Utilization of oil palm fronds as a sustainable carbon source in biorefineries. International Journal of Hydrogen Energy, 41(8), 4896-4906. https://doi.org/10.1016/j.ijhydene.2015.08.034

Tumulu, J. S., Sokhansanj, S., Wright, C. T., \& Boardman, R. D. (2011). A review on biomass torrefaction process and product properties for energy applications. Industrial Biotechnology, 7(5), 384-401. https://doi.org/10.1089/ind.2011.7.384

Uemura, Y., Omar, W., Tsutsui, T., \& Yusup, S. (2011). Torrefaction of oil palm wastes. Fuel, 90, 2585-2591. https://doi.org/10.1016/j.fuel.2011.03.021

Umar, M. S., Jennings, P., \& Umee, T. (2014). Generating renewable energy from oil palm biomass in Malaysia: The Feed-in Tariff policy framework. Biomass and Bioenergy, 62, 37-46. https://doi.org/10.1016/j.biombioe.2014.01.020

Van der Stelt, M. J. C., Gerhauser, H., Kiel, J. H. A., \& Ptasinski, K. J. (2011). Biomass upgrading by torrefaction for the production of Biofuels: A Review. Biomass and Bioenergy, 35, 3748-3762.

Wahid, F. R., Saleh, S., \& Samad, N. A. (2017). Estimation of higher heating value of torrefied palm oil wastes from proximate analysis. Energy Procedia, 138, 307-312. https://doi.org/10.1016/j.egypro.2017.10.102

Wahid, M. W., \& Simeh, M. A. (2010). Accelerated oil palm replanting: the way forward for a sustainable and competitive industry. Oil Palm Industry Economic Journal, 10, 29-38.

Zahari, M. W., Abu Hassan, O., Wong, H. K., \& Liang, J. B. (2003). Utilization of oil palm frond - based diets for beef and dairy production in Malaysia. Asian-Australasian Journal of Animal Sciences, 16(4), 625-634.

Zhang, C., Ho, S.-H., Chen, W.-H., Xie, Y., Liu, Z., \& Chang, J.-S. (2018). Torrefaction performance and energy usage of biomass wastes and their correlations with torrefaction severity index. Applied Energy, 220, 598-604.

https://doi.org/10.1016/j.apenergy.2018.03.129 